\title{
PENERAPAN HACCP PENGOLAHAN MAKANAN DENGAN ANGKA KUMAN PADA MAKANAN KETOPRAK DI BANDAR LAMPUNG
}

\author{
Amelia Rohmah ${ }^{1)}$
}

\begin{abstract}
Abstrak
Hazard Analysis Critical Control Point (HACCP) untuk menilai bahaya dan membentuk sistem pengendalian yang berfokus pada pencegahan. Ketoprak merupakan makanan jajanan yang di jual oleh pedagang kaki lima sehingga memiliki tingkat kerentanan yang tinggi. Tujuan penelitian ini adalah untuk mengetahui hubungan pengamanan makanan dengan angka kuman pada makanan.

Jenis penelitian adalah deskriptif analitik dengan rancangan cross sectional. Populasi dalam penelitian ini adalah seluruh pedagang ketoprak yang berjualan di Bandar Lampung. Sampel diambil berdasarkan teknik klaster dan diperoleh sampel sebanyak 32 pedagang ketoprak. Pengumpulan data dengan wawancara, observasi, dan penilaian angka kuman makanan dengan metode angka lempeng total (ALT). Analisis data menggunakan uji Chi Square, untuk menilai hubungan hasil faktor risiko cemaran dengan angka kuman pada pangan makanan.

Hasil penelitian mendapatkan sebanyak $18,8 \%(\mathrm{~N}=32)$ sampel makanan mengandung bakteri, dan $21,9 \%$ pedagang belum menerapkan pengamanan makanan. Risiko pedagang tidak menerapkan pengamanan makanan dengan baik meningkatkan risiko 60,0 (4,52-97,08) kali. Perlu upaya bersama untuk meningkatkan pengetahuan dan keterampilan pedagang dalam menerapkan prinsip-prinsip hygiene sanitasi pengelolaan makanan.
\end{abstract}

Kata Kunci: HACCP, ketoprak, angka kuman

1) Alumni Jurusan Kesehatan Lingkungan Poltekkes Kemenkes Tanjungkarang

\section{PENDAHULUAN}

Makanan berguna untuk membangun jaringan tubuh yang baru, memelihara, dan memperbaiki jaringan tubuh yang sudah tua, dan makan sebagai zat pengatur karena makanan turut serta mengatur proses alam, kimia, dan proses faal dalam tubuh (Chandra, 2005). Pada dasarnya, manusia memerlukan makanan yang memenuhi syarat-syarat, antara lain enak rasanya, bersih dan sehat, memenuhi gizi yang cukup, mudah dicerna dan diserap oleh tubuh, bebas dari cemaran mikroba. Sedangkan faktor-faktor lingkungan yang mempengaruhi makanan adalah: 1) Lingkungan fisik, meliputi: air, udara, tanah, sinar, suhu, kelembaban; 20 Lingkungan kimia, meliputi : pestisida, food additive, antibiotika, dan logam; 3) Lingkungan biologis meliputi jasad renik, manusia, hewan ternak/piaraan, binatang piaraan/tikus, dan tanaman atau tumbuhan. Oleh karena itu, makanan dan minuman yang dikonsumsi haruslah terjamin baik dari segi kualitas dan kuantitasnya (Ahyanti, 2018).

Salah satu usaha menjamin mutu dan keamanan makanan sejak proses produksi hingga ke tangan konsumen adalah Hazard Analysis Critical Control Point (HACCP), yaitu penilaian bahaya dan menetapkan sistem pengendalian yang memfokuskan pada pencegahan dari pada mengandalkan sebagian besar pengujian produk akhir terhadap hygiene dan sanitasi makan dan minuman utamanya adalah usaha yang diperuntukkan untuk umum seperti rumah sakit, restoran, rumah makan, atau pedagang kaki lima mengingat bahwa makan dan minuman merupakan media yang potensial dalam penyebaran penyakit (Winanro, 1993; Depkes RI, 2004).

Pada penelitian Djaja (2003) yang dikutip oleh Pratidina (2017) dan Atmoko (2017), dari tiga tempat pengelolaan makanan (TPM) menyimpulkan bahwa pedagang kaki lima berisiko 3,5 kali lipat terhadap terjadinya kontaminasi makanan dibandingkan dengan usaha jasaboga, restoran dan rumah makan. Ketoprak merupakan salah satu makanan jajanan khas Indonesia menggunakan ketupat yang mudah dijumpai menggunakan gerobak dijalan-dijalan atau dikaki lima, didalam ketoprak terdapat tahu, bihun, mentimun, touge, 
dan lain-lain. Ketoprak dapat menjadi salah satu media penularan penyakit yang diakibatkan oleh makanan yang tidak sehat. Kontaminasi pada makanan berupa virus, bakteri, jamur, parasit, dan bahan kimia berbahaya. Sebagai gambaran, berdasarkan Foodborne Disease Burden Epidemiologi Reference Group (FERG) 2010 dari WHO, diperkirakan 582 juta kasus muncul dari 22 penyakit yang menyebarkan melalui makanan (Foodborne Disease). Sebanyak 351.000 diantaranya berujung kematian.

Di Indonesia pada tahun 2017, berdasarkan data dari Direktorat Kesehatan Lingkungan dan Public Health Emergency Operation Center (PHEOC) Kementerian Kesehatan mencatat KLB keracunan pangan berjumlah 163 kejadian, 7132 kasus dengan Case Fatality Rate (CFR) 0,1\%. KLB keracunan pangan termasuk urutan ke-2 dari laporan KLB yang masuk ke PHEOC, Nomor 2 setelah KLB difteri. Di Provinsi Lampung pada tahun 2012 frekuensi kejadian luar biasa (KLB) terdapat 4 kejadian keracunan pangan yang dilaporkan ke BPOM. Dengan jumlah kasus sebanyak 57 orang sakit dan dirawat. Kasus KLB keracunan pangan merupakan fenomena gunung es, artinya tidak semua kasus atau kejadian dapat dilaporkan (BPOM RI, 2012). Hasil penelitian Laseri (2017) pada pedagang makanan jajanan mendapatkan sebanyak $51 \%$ memiliki pengetahuan yang buruk dan $49 \%$ memiliki pengetahuan yang baik. Hal ini menunjukan bahwa pengetahuan pedagang kaki lima masih buruk yang sangat berpengaruh pada angka kuman makanan dalam pengawasan pada makanan.

Hasil studi pendahuluan (6 Januari 2019) terhadap 10 penjual ketoprak diketahui masih banyak pedagang yang kurang memperhatikan aspek hygiene dan sanitasi, seperti kebersihan tangan, air pencucian, penyimpanan bahan makanan dalam keadaan terbuka. Penelitian bertujuan mengetahui hubungan pengamanan makanan dengan angka kuman pada makanan ketoprak di Bandar Lampung.

\section{METODE}

Jenis penelitian yang digunakan adalah deskripsi analitik dengan rancangan cross sectional yaitu penelitian yang mempelajari dinamika korelasi antara faktor-faktor risiko dengan efek, dengan cara pendekatan, observasi atau pengumpulan data sekaligus pada suatu saat. (Notoatmodjo, 2014). Lokasi penelitian di Kota Bandar Lampung, pada bulan Februari - Mei 2019. Populasi adalah seluruh pedagang ketoprak di 20 kecamatan yang ada di Kota Bandar Lampung, sebanyak 115 pedagang. Pengambilan sampel dilakukan secara purposive di empat kecamatan terpadat (Kecamatan Teluk Betung Timur, Teluk Betung Barat, Teluk Betung Utara, Teluk Betung Selatan), sebanyak 32 pedagang.

Data dikumpulkan melalui wawancara dan observasi, untuk mengetahui cara pengolahan makanan, mulai dari pembuatan hingga penyajian makanan. Penilaian HACCP (identifikasi bahaya, penetapan CCP, penetapan batas kritis, pemantauan CCP, tindakan koreksi terhadap penyimpangan, verifikasi, dokumentasi) dilakukan pada setiap tahapan pembuatan makanan (Gambar 1). Pemeriksaan angka kuman makanan juga dilakukan menggunakan metode Angka Lempeng Total (ALT), mengikuti Ahyanti (2019).

Keseluruhan data dianalisis secara univariat (frekuensi dan proporsi), dan bivariate dengan Chi-square pada alpha=0,05. Analisis menggunakan perangkat SPSS, dan hasilnya disajikan dalam bentuk tabel dan gambar.

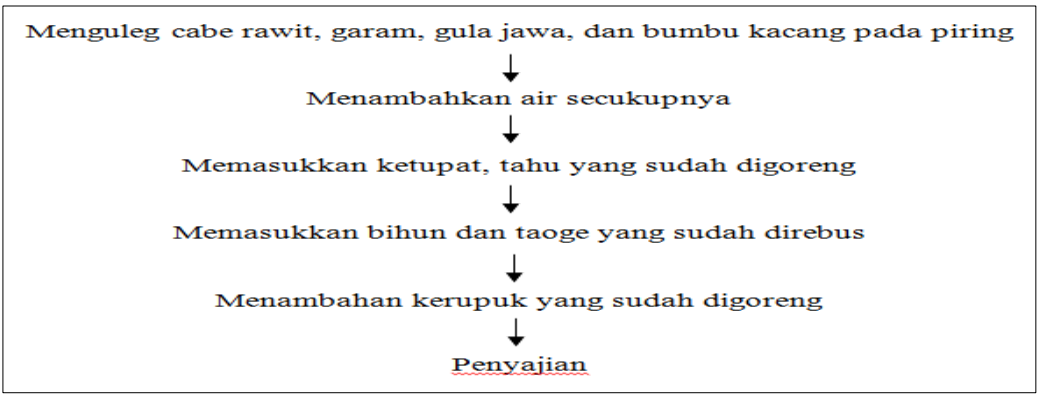

Gambar 1. Diagram alir proses pengolahan makanan ketoprak 


\section{HASIL}

\section{Identifikasi bahaya}

Tabel 1 menyajikan identifikasi bahaya dengan penerapan HACCP pada pengolahan makanan ketoprak. Kelompok risiko atau bahaya dikelompokkan menjadi tiga, yaitu fisik, kimia, dan mikrobiologis. Faktor fisik adalah paparan debu dan asap kendaraan bermotor. Kimia berupa paparan pestisida, pengawet, pewarna makanan, sodium laurit sulfat. Sedangkan faktor mikrobiologis dari kontaminasi, predominan, dan serangga.

Hasil penelitian mendapatkan bahwa risiko paling banyak berada pada kelompok bahaya B, yaitu mengandung bahaya bahan yang sensitive terhadap bahaya biologis/kimia/fisik, seperti pada bumbu-bumbu yang digunakan (cabe rawit, bawang merah, bawang putih, garam, gula merah, asam jawa, kacang goreng), dan tahapan kerja (menghaluskan bumbu di piring, memotong ketupat, memotong tahu, penambahan bihun, kerupuk, saat penyajian ke pelanggan dan pencucian piring).

Sedangkan pada kelompok bahaya $\mathrm{C}$, yaitu tidak ada upaya untuk mencegah/ menghilangkan bahaya terjadi pada bihun dan tahu yang mengandung pengawet. Hasil identifikasi disajikan pada Tabel 1.

Tabel 1. Identifikasi Bahaya dengan HACCP

\begin{tabular}{|c|c|c|c|c|c|}
\hline \multirow[t]{2}{*}{ No. } & \multirow[t]{2}{*}{ Bahan/ masakan } & \multicolumn{3}{|c|}{$\begin{array}{c}\text { Kelompok } \\
\text { Risiko } \\
\end{array}$} & \multirow[t]{2}{*}{ Cara Pencegahan } \\
\hline & & $\mathbf{F}$ & $\mathbf{K}$ & $\mathbf{B}$ & \\
\hline 1 & $\begin{array}{l}\text { Cabe rawit, bawang merah, } \\
\text { bawang putih, garam, gula } \\
\text { merah, asam jawa, kacang } \\
\text { goreng }\end{array}$ & $\mathrm{Y}$ & $\mathrm{Y}$ & $\mathrm{Y}$ & $\begin{array}{l}\text { Dicuci dengan air mengali hingga bersih sesaat } \\
\text { sebelum diolah, merendam garam yang ditanam } \\
\text { dengan garam dapur, disimpan dalam toples tertutup. }\end{array}$ \\
\hline 2 & Tauge & $\mathrm{Y}$ & $\mathrm{Y}$ & & Menjaga wadah tetap bersih dan tertutup. \\
\hline 3 & Bihun dan tahu & $\mathrm{Y}$ & & & $\begin{array}{l}\text { Lebih selektif memilih bahan, kenali cirri bahan } \\
\text { makanan yang tidak bagus, menjaga wadah tetap bersih } \\
\text { dan tertutup. }\end{array}$ \\
\hline 4 & $\begin{array}{l}\text { Menghaluskan bumbu } \\
\text { langsung di piring }\end{array}$ & $\mathrm{Y}$ & & $\mathrm{Y}$ & Penjamah menggunakan masker. \\
\hline 5 & Menambahan air secukupnya & $\mathrm{Y}$ & $\mathrm{Y}$ & $\mathrm{Y}$ & $\begin{array}{l}\text { Merebus air sampai mendidih, pastikan wadah tidak } \\
\text { berkarat, apabila wadah berbahan plastik jangan } \\
\text { masukan air ketika masih panas. }\end{array}$ \\
\hline 6 & Pemotongan ketupat ke piring & $\mathrm{Y}$ & & $\mathrm{Y}$ & $\begin{array}{l}\text { Disimpan di tempat tertutup dan tidak terlalu lama dari } \\
\text { pembuatan ketupat, menggunakan pisau khusu suntuk } \\
\text { memotong ketupat saja. }\end{array}$ \\
\hline 7 & Pemotongan tahu ke piring & $\mathrm{Y}$ & & & $\begin{array}{l}\text { Menggunakan pisau khusus dipakai memotong tahu } \\
\text { saja. }\end{array}$ \\
\hline 8 & Penambahan bihun & $\mathrm{Y}$ & & $\mathrm{Y}$ & Menggunakan alat atau sendok yang bersih. \\
\hline 9 & Penambahan tauge & $\mathrm{Y}$ & & $\mathrm{Y}$ & Menggunakan alat atau sendok yang bersih. \\
\hline 10 & Penambahan krupuk & Y & & Y & Menggunakan alat atau sendok yang bersih. \\
\hline 11 & Penyajian kepelanggan & $\mathrm{Y}$ & & $\mathrm{Y}$ & Mengantarkan makanan menggunakan penutup. \\
\hline 12 & Pencucian piring & $\mathrm{Y}$ & $\mathrm{Y}$ & $\mathrm{Y}$ & $\begin{array}{l}\text { Piring harus benar benar bersih, dicuci dengan air } \\
\text { mengalir, dicuci dengan air hangat kuku atau sekitar } \\
30^{\circ} \mathrm{C}\end{array}$ \\
\hline
\end{tabular}

Hasil penilaian dengan HACCP (mulai dari identifikasi bahaya sampai dengan tindakan koreksi) selanjutnya dikelompokkan menjadi dua (Tabel 2). Sebanyak $78,1 \%$ pedagang masuk dalam kategori baik, dan 21,9\% masuk dalam kategori kurang baik.
Tabel 2. Frekuensi Angka Kuman dan HACCP

\begin{tabular}{lcc}
\hline \multicolumn{1}{c}{ Variabel } & n & \% \\
\hline HACCP & & \\
$\quad$ Baik & 25 & 78,1 \\
$\quad$ Buruk & 7 & 21,9 \\
Angka Kuman & & \\
$\quad$ Memenuhi syarat & 26 & 81,3 \\
$\quad$ Tidak memenuhi syarat & 6 & 18,8 \\
\hline
\end{tabular}


Berdasarkan hasil pemeriksaan angka kuman pada makanan, ditemukan sebanyak 18,8\% sampel mengandung kuman, dan sisanya $(81,2 \%)$ tidak ditemukan, atau telah memenuhi syarat kesehatan (Tabel 2).

\section{Pengamanan Makanan dan angka kuman}

Pada Tabel 3 terlihat bahwa mayoritas $(71,4 \%)$ sampel makanan yang tidak memenuhi syarat, berasal dari pedagang dengan pengamanan makanan kurang baik. Pada sampel yang bebas angka kuman, mayoritas $(96,0 \%)$ berasal dari pedagang yang melakukan pengamanan makanan. Hasil analisis statistik menunjukkan hubungan antara pengamanan makanan dengan angka kuman pada makanan (p-value $<0,05$ ). Peluang terdapat kuman pada makanan $60,0(4,52-97,08)$ kali pada pedagang yang tidak menerapkan pengamanan makanan dengan baik.

Tabel 3. Hubungan Penerapan HACCP dan Angka Kuman

\begin{tabular}{|c|c|c|c|c|c|c|}
\hline \multirow{3}{*}{ НАССР } & \multicolumn{4}{|c|}{ Angka Kuman Makanan } & \multirow{3}{*}{$\mathrm{p}$-value } & \multirow{3}{*}{ CI:95\% } \\
\hline & \multicolumn{2}{|c|}{ TMS } & \multicolumn{2}{|c|}{ MS } & & \\
\hline & $\mathrm{n}$ & $\%$ & $\mathrm{n}$ & $\%$ & & \\
\hline Kurang Baik & $\begin{array}{l}5 \\
1\end{array}$ & 71,4 & 2 & 28,0 & 0,0001 & $\begin{array}{c}60,0 \\
620708\end{array}$ \\
\hline
\end{tabular}

\section{PEMBAHASAN}

\section{Identifikasi bahaya pada pengolahan} makanan ketoprak

Berdasarkan pemeriksaan angka kuman pada makanan ketoprak yang dijual oleh pedagang di Kota Bandar Lampung, sebanyak 6 sampel $(18,8 \%)$ eridentifikasi tercemar oleh bakteri. Namun, $26(18,2 \%)$ sampel telah memenuhi syarat kesehatan. Menurut Kemenkes RI (2011) dan Peraturan Kepala BPOM RI No.16 tahun 2016 tentang kriteria mikrobiologi dalam pangan olahan, angka kuman pada makanan tidak boleh ada.

Bahan pangan dapat bertindak sebagai perantara atau substrat untuk pertumbuhan mikroorganisme patogen penyebab penyakit. Penyakit menular yang cukup berbahaya seperti tifus, kolera, disentri, atau TBC, mudah tersebar melalui bahan makanan (Hafidawati, 2012). Berdasarkan karakteristik pangan, pertumbuhan mikroba dipengaruhi oleh jumlah air yang tersedia pada makanan, nilai keasaman $(\mathrm{pH})$, kandungan gizi, dan senyawa anti mikroba. Sedangkan berdasarkan kondisi lingkungan, pertumbuhan mikroba dipengaruhi oleh suhu, keberadaan oksigen, dan kelembaban. Selain itu, mikroba pada makanan disebabkan oleh kontaminasi dari tangan penjamah makanan yang tidak menjaga kebersihan selama bekerja. Menurut Irianto dalam Hafidawati (2012), terdapatnya kuman pada makanan akibat perpindahan kuman dari tangan ke makanan.

Terdapatnya kuman pada makanan disebabkan oleh rendahnya pengawasan pada makanan, sejak dari bahan baku, pengolahan, hingga penyajian. Pengawasan pangan dapat memberikan jaminan mutu dan keamanan pangan. Salah satunya adalah dengan HACCP, yaitu metode untuk menilai bahaya dan menetapkan sistem pengendalian yang memfokuskan pada pencegahan. Setiap sistem HACCP mampu mengakomodasi perubahan, seperti kemajuan dalam rancangan peralatan, prosedur pengolahan atau perkembangan teknologi. HACCP dapat diterapkan pada seluruh rantai pangan dari produk primer sampai pada konsumsi akhir dan penerapannya harus diperoleh dengan bukti secara ilmiah terhadap resiko kesehatan manusia (BSN, 1997 dalam Pratikto 2013). Tujuan dari diberlakukannya HACCP adalah: a) Untuk menjamin bahwa produksi pangan setiap saat; b) Merupakan bukti sistem produksi dan penangan produk yang aman; c) Memberi rasa percaya diri pada produsen akan jaminan keamanan produknya; d) Memberikan kepuasan kepada customer akan konformitasnya pada standar nasional/internasiona; e) Memenuhi standar regulasi pemerintah; f) Penggunaan sumber daya secara efektif dan efisien.

Untuk menghindari adanya kuman pada makanan, maka penjamah makanan harus menerapkan keamanan pada makanan mulai dari persiapan bahan makanan, pengolahan, peralatan masak yang digunakan, lingkungan dan tempat mengolah makanan, peralatan makan, tempat menyimpan makanan. Hal penting lainnya adalah cara mencuci, air yang digunakan, serta penyimpanan alat masak dan alat makan. 


\section{Penerapan HACCP dan angka kuman makanan}

Hasil penelitian mendapatkan bahwa sebagian besar $(71,4 \%)$ sampel makanan yang tidak memenuhi syarat, berasal dari pedagang dengan pengamanan makanan kurang baik. Pada sampel yang bebas angka kuman, mayoritas $(96,0 \%)$ berasal dari pedagang dengan pengamanan makanan baik. Hasil analisis statistik menunjukkan hubungan antara pengamanan makanan dengan angka kuman pada makanan ( $\mathrm{p}$-value $<0,05)$. Peluang terdapat kuman pada makanan 60,0 (4,52-97,08) kali pada pedagang yang tidak menerapkan pengamanan makanan dengan baik (Tabel 3).

Untuk mengetahui penerapan HACCP telah dilakukan dengan baik, maka perlu dilakukan pemeriksaan angka kuman. Makanan dan minuman yang baik adalah makanan dan minuman yang bebas dari bakteri-bakteri patogen. Upaya pengamanan makanan dan minuman pada dasarnya melakukan pengamanan/pencegahan kontaminasi dari orang yang menangani makanan, tempat penyelenggaraan makanan, peralatan pengolahan makanan dan proses pengolahan nya. Ada beberapa aktor yang mempengaruhi terjadinya keracunan makanan, antara lain higienis perorangan yang buruk, cara penanganan makanan yang tidak sehat, dan perlengkapan pengolahan makanan yang tidak bersih.

Menurut Winarno (1993), masalah keamanan pangan banyak ditimbulkan karena kondisi hygiene dan sanitasi yang rendah sehingga mengakibatkan kontaminasi bahan pangan baik pada makanan maupun minuman yang dijual di pinggir jalan, warung-warung atau dibuat di rumah penduduk. Keamanan makanan diselenggarakan untuk menjaga makanan tetap aman, higienis, bermutu, bergizi, dan tidak bertentangan dengan agama, keyakinan, dan budaya masyarakat. Keamanan makanan dimaksudkan untuk mencegah kemungkinan cemaran biologis, kimia, dan benda lain yang dapat mengganggu, merugikan, dan membahayakan kesehatan manusia. Masalah sanitasi pangan banyak berkaitan dengan kebersihan dari tahap produksi, persiapan, penyimpanan, dan penyajian makanan. Disamping itu, pengelolaan makanan juga harus memperhatikan kebersihan pekerja, peralatan dan air yang digunakan selama proses persiapan, pengolahan dan penyajian, tempat sampah yang memadai dan peralatan yang cukup.

Sudarmaji dalam Jemis (2013) menyampaikan, bahwa suatu pendekatan sistem dalam pengamanan makanan adalah dengan pendekatan HACCP. Pengawasan keamanan makanan dapat terjamin mutu makanan, karena setiap tahapan proses pengolahan dilakukan pengendalian risiko dan bahaya yang timbul. Sehingga, untuk menerapkan HACCP diperlukan peningkatan mutu sumber daya manusia agar tercapai sasaran. Untuk mengatasi kekurangan dalam pengukuran kinerja tersebut, maka digunakan suatu metode pendekatan yang mengukur kinerja perusahaan yang mengedepankan pentingnya menyelaraskan aspek perusahaan secara keseluruhan, meliputi investor, customer, tenaga kerja, supplier, peraturan dan masyarakat.

Oleh karena itu, untuk mendapatkan makanan yang layak untuk dikonsumsi, maka perlu dilakukan pengamanan makanan yang memprioritaskan pada aspek pencegahan. Diperlukan upaya bersama untuk meningkatkan pengetahuan pedagang atau penjamah makanan dalam pengamanan makanan, baik melalui penyuluhan, maupun pelatihan.

\section{KESIMPULAN}

Hasil penelitian mendapatkan sebanyak 6 $(18,8 \%)$ sampel makanan jenis ketoprak yang diperiksa dengan metode ALT, mengandung bakteri, dan 7 (21,9\%) pedagang belum menerapkan pengamanan makanan. Hasil analisis statistik menunjukkan hubungan antara penerapan HACCP dengan angka kuman pada makanan ( $\mathrm{p}$-value $<0,05)$. Peluang terdapat kuman pada makanan 60,0 (4,52-97,08) kali lebih besar pada pedagang yang tidak menerapkan pengamanan makanan dengan baik. Rendahnya pengetahuan pedagang mengakibatkan tidak dilakukannya penerapan pengamanan makanan, sehingga terjadi kontaminasi dari lingkungan dan penjamah. Perlu upaya bersama untuk meningkatkan pengetahuan dan keterampilan pedagang dalam mengolah makanan yang sesuai dengan prinsipprinsip keamanan makanan.

\section{DAFTAR PUSTAKA}

Ahyanti, Mei. 2018. Penyehatan Makanan dan Minuman. Pustaka Panasea. Yogyakarta.

Ahyanti, Mei. 2019. Modul Praktikum Penyehatan Makanan dan Minuman-A, 
Yayasan Bina Masyarakat Mandiri. Bandar Lampung.

Atmoko, Hadi; Hanani, Hanan. 2017. Peningkatan Hygiene Sanitasi SebgI Upaya Menjaga Kualitas Makanan Dan Kepuasan Pelanggan Di Rumah Makan Dhamar Palembang; Jurnal Khasanah Ilmu-Volume 8 No. 1-2017. Hal 1-9

BPOM RI, 2012, Laporan Tahunan Badan Pengamanan Obat-obatan dan Makanan, Lampung.

BPOM RI.16. Peraturan Kepala BPOM tahun 2016 tentang Kriteria Mikrobiologi Dalam Pangan Olahan.

Chandra, Budiman. 2006. Pengantar Kesehatan Lingkungan. Buku Kedokteran. Jakarta.

Depkes RI. 2004. Higiene Sanitasi Makanan dan Minuman. Dirjen PPM dan PLP. Depkes RI Jakarta.

Hafidawati, dkk. 2012. Penuntun Praktikum Laboratorium Lingkungan. Universitas Riau. Pekanbaru. http://Penuntun Praktikum Laboratorium Lingkungan.ac.id.unrau (diakses pada tanggal 28 April 1019)

Pratikto, Hermansyah; Soenoko, Setyanto. 2013. Hazard Analiziz And Critical Control Point (HACCP) Produksi Maltossa
Dengan Pendekatan Good Manufacturing Practice (GMP); Jemis Vol. 1 NO. 1 tahun 2013 hal. 14-20

Laseri, Tri Era. 2017. Hubungan Hygiene Sanitasi dan Prilaku Penjamah Makanan Dengan Angka Kuman pada Makanan Jajanan di Lingkungan Sekolah Yayasan Kartika Jaya Kota Bandar Lampung. Skripsi. Poltekkes.

Notoatmodjo, Soekidjo. 2014. Metodologi Penelitian Kesehatan. Jakarta. Rineka Cipta.

Kemenkes RI. 2011. Peraturan Menteri Kesehatan Republik Indonesia Nomor 1096 Tentang Higiene Sanitasi Jasaboga, Jakarta.

Pratidina, Azzahra. 2017. Hubungan Hygiene Dan Sanitasi Dengan Kontaminasi Ec Pada Jajanan Pedagang Kaki Lima Disekolah Dasar Kelurahan Pendrikan Lor, Semarang; Jurnal Kesehatan Masyarakat(eJournal) Volume 5, Nomor 5, Oktober 2017 (ISSN: 2356-3346) http://ejournal3.undip.ac.id/index.php/jkm. (diakses pada 4 Februari 2019)

Winanro, Florentinus Georgius, 1993. $H A C C P$ dan penerapannya dalam industri pangan. M-Brio. Press. 